\title{
Capital market and economic growth in Nigeria
}

\author{
KEJI Sunday Anderu
}

\author{
Department of Economics, Federal University Oye-Ekiti, Ekiti State, Nigeria
}

Correspondence author email: sunday.keji@fuoye.edu.ng

\begin{tabular}{|l|l|l|l|l|}
\hline DOI: & Received: & Revised: & Accepted: & Published: \\
10.22437/ppd.v8i3.9652 & 15.06 .2020 & 01.08 .2020 & 07.08 .2020 & 31.08 .2020 \\
\hline
\end{tabular}

\begin{abstract}
The objective of this study is to empirically examine the nexus between capital market and economic growth in Nigeria between 1980 and 2017. In the cause of pursuing the desired result, the economic growth was proxy by the gross domestic product (GDP) while the capital market variables considered included market capitalization, all shares index, number of dealings, gross capital formation, exchange rate, value of all transaction and interest rate. This study is predated by the ineffectiveness of capital market which affects liquidity, acquisition of information about firms such as risk diversification, savings harmonization and corporate management. In lieu of this, the research adopted Auto-regressive Distribution Lag model and Bound Cointegration Testing. The results revealed that there is long run relationship between capital market and economic growth in Nigeria. To justify the findings, post estimation tests were conducted. For instance, the Jarque-Beta test suggest that the residuals for both models are normally distributed since the probability value is greater than 5\% significant level. Hence, the hypothesis of normal distribution for residuals cannot be rejected. The Breusch-Godfrey Serial Correlation (LM) test re-affirms that the hypothesis of no autocorrelation can be rejected since the probability value is greater than $5 \%$ critical value. Henceforward, the study recommends that government should expand the market technological based in order to further improve transactions and dealings, which could enhance its internationalization and competitiveness. Also, regulatory body like security and exchange commission (SEC) should improve its supervisory roles towards reducing shoddy and unethical dealings in the Nigerian capital market.
\end{abstract}

Keywords: Capital market, Economic growth, Security.

JEL Classification: G11 O16 O43

\section{INTRODUCTION}

The overall growth of an economy depends on how efficiently and effectively her capital market performs, aided with smooth allocation and mobilization of funds. This is derived from it vital roles it plays through the appropriate fund channelization and 
financial intermediation strength of the sector by linking the surplus resources to deficit resources sector of the economy that is mobilization and allocation of funds that are germane to local investment drive (Alile, 1984). Similarly, Osaze (2000) opined capital market as an in-built stabilizer of any nation to growth since capital formation via longterm loans are vital for economic growth. Also, Ekundayo (2002) posits that a nation need much of local and foreign investments to achieve sustainable economic growth and development. Drawing from this assertion, the security market offers several means through which this is achievable and this essential role is important in determining the aggregate growth of the economy.

However, macroeconomic instability and unorganized financial system which have retarded financial mobilization through saving and investment in Nigeria have been major concerns. Also, the paucity of long-term capital has created a demanding challenge to economic growth in several African countries, especially, Nigeria. In Nigeria for example, the ineffectiveness of capital market affects liquidity, acquisition of information about firms, risk diversification, savings harmonization and corporate management (Anyanwu, 1998) Capital market financing creates no short term repayment period as funds are held for medium and long term period or in infinity, funds to different tiers of government without pressures and sufficient time to repay loans. The current clamor for expansion of local investment to stabilize economic growth after the recent economic recession cannot therefore be overemphasized, and hence the relevance of this study at this essential period. In addition, with the previous consequential effect of poor capital market development which creates further problems for the nation's development particularly, the present scenario of economic recession that disrupts potential rise in Nigeria's economic growth.

Consequently, fewer attempts have been made in the past by previous scholars like Afeez \& Kazeem (2010), Aremu, Suberu, \& Ladipo (2011), Oke \& Azeez (2012), Godfrey \& Mutuku (2013) but with diverse views to unravel the ugly trend affecting economic in Nigeria. Going forward, it is pertinent in this study to focus on the problems rise from recent economic recession which disrupts growth stability. Interestingly, the noticeable problems stated were the motivating factors behind this study.

On this note, different questions have been raised which this research intended to answer. Firstly, following questions: what is the relationship between capital market and the Nigerian economic growth? Secondly, what is the direction of capital market trend on economic growth indicator? While, the objective of the study is to empirically investigate the relationship between capital market and economic growth in Nigeria. The outcomes from this study shall be of great value to both the government and policy makers based on the findings and recommendations this study may provide.

Furthermore, this study covers the period of 1980-2017, a period of thirty-seven years. This period is particularly pertinent for the study and the nation's economic history because it covers a period of deficit financing of long term projects as well as recessionary period in general which emanated as a result of low level of savings in Nigerian economy. Again, the choice of this period is necessitated by the undesirable macro-economic problems, economic distress and fluctuations that disrupts capital market liquidity flows.

This research is divided into five sections; section one encompasses the introductory aspect. Chapter two explains the conceptual, theoretical and empirical 
literature review, while chapter three addresses the methodology, while chapter four encompasses the data representation and analysis. Whereas, chapter five therefore contains the conclusion, and policy recommendations.

\section{LITERATURE REVIEW}

Capital market is termed as complex institutions with diverse mechanisms through which intermediate term of trade and long term funds are polled. Notably, capital market is of different forms; the primary capital market and the secondary capital market. The primary market is the market for new issues that provide avenues to both government and corporate firms to rise fresh funds via securities issuance with general or selected group of investors subscribed from. While the secondary market is the market that offers the platform for sales and purchases of the already existing securities.

\section{The relevant roles of the capital market in Nigeria}

The roles of capital market in Nigeria cannot be over-emphasized. The following roles are mostly performed by capital market in the growth of the Nigerian economy include: (1) It allows prospects for companies to secure funds needed for long-term investment drives; (2) It creates avenue for the marketing of securities (e.g. shares, bonds etc.) so as to raise fresh funds for development of operations that brings about increase in output/production; (3) It paves ways for allocation of the nation's real and financial resources between various industries and companies. That is, via the capital formation and allocation device to the capital market which guarantees an efficient and effective supply of the scarce funds for the optimal benefit to the economy; (4) It lessens the over dependence of the corporate sector on short term financing for long term projects and also provides ways for government to finance projects aimed at providing essential amenities for local investors; (5) The capital market boosts the government efforts in its privatization drives by given her shares in the public enterprises to members of the public through the stock exchange; (6) The capital market also encourages the foreign capital inflow when foreign companies or investors invest in domestic securities, and this provides needed seed money for productive capital development and acts as a reliable medium for broadening the ownership base of family-owned and dominated firms.

\section{Capital market concepts}

The Financial Market; this market can have termed as intermediary market through which necessary funds are been mobilized across the security market. The international market in recent years have grown over the world in a very fast pace. "The buoyant capital flows among the nation boundaries have raised the existing strength of the financial market domestically as well as internationally" (Aremu et al, 2012). In Worldwide perspectives, particularly the financial markets are mainly affected by the hedge funds. The use of hedge funds has allowed the trading activities with large number of dealers. Notably, traditionally the banks were tasked with lending and receiving deposits. In the recent times, financial market among the countries over the world are the main area of concerns in the financial activities with execution of large deposits to the security market. Meanwhile, the financial markets can be divided into money and capital market.

Money markets are Markets for borrowing and lending funds for short-term 
investment. The securities in a money market can be government bonds, Treasury bills and commercial paper from banks and companies.

The market is neither not a place nor a particular spot, however, it is the continuous buying and selling of short-term securities or liquid for investments. That is, trading of vastly liquid, short-term assets and securities, for example, treasury bills and commercial paper. Investors could trade on the money market either inform of an exchange or overthe counter.

The capital Market on the other hand is a market where long term funds are source by both government and companies to trade securities on the bond and the stock market. The market comprises of both the primary market where new liquidities are distributed among investors, and the secondary markets where already existing securities are bought and sold. Notably, mortgages, bonds, equities and other securities are traded in the capital market, and these liquidities serve as investment funds. The market also mobilizes funds from scarce spots to excess spots i.e. it creates the process whereby investors with much funds would able to channel them to investors in deficit.

\section{Stock market key indicators}

Market Capitalization Ratio (MCR): This is equals to the values of all listed shares divided by GDP. This is believed that it estimates the overall market size which is positively associated with the ability to diversify risk and mobilize capital on an economywide basis.

Total Value of Shares Traded Ratio (STR): This is equals to total values of shares traded on the floor of stock market exchange divided by GDP. The total value traded ratio estimates the systematized trading of firm equity as a share of country's produce which hence positively reflect liquidity on an economy-wide basis. This is used to complements the market capitalization ratio: although a market may be big, there might be little trading.

Turnover Ratio (TR): Turnover ratio equals the values of total shares traded divided by market capitalization. Nonetheless it is not a straight method of theoretical definitions of liquidity, high turnover usually used as a pointer of low operation costs. The market capitalization ratio is being complemented by turnover ratio. A large which is inactive dealings would have a huge market capitalization ratio but a small turnover ratio. Turnover also complements the total value traded ratio. Whereas, the total value traded ratio captures trading relative to the size of the economy, turnover captures trading relative to the stock market size. A small total value traded ratio sets in when a small liquid market has a high turnover ratio.

\section{Related growth theories}

Several theoretical contributions have been made as regards the subject matter of capital and economic growth. These theories are of relevance to this study as they serve as a foundation to this research work and as such the following theory will be discussed; Solow-growth model.

\section{The Harrod-Domar Growth Model}

Every economy must save a certain proportion of its national income, if only to replace worn-out or impaired capital goods (buildings, equipment, and materials).

However, in order to grow, new investments representing net additions to the capital 
stock are necessary. If we assume that there is some direct economic relationship between the size of the total capital stock, $\mathrm{K}$, and total GNP, Y-for example, if $\$ 3$ of capital is always necessary to produce a $\$ 1$ stream of GNP - it follows that any net additions to the capital stock in the form of new investment will bring about corresponding increases in the flow of national output, GNP. Suppose that this relationship, known in economics as the capital-output ratio, is roughly 3 to 1 . If we define the capital-output ratio as $\mathrm{k}$ and assume further that the national savings ratio, $\mathrm{s}$, is a fixed proportion of national output (e.g., 6\%) and that total new investment is determined by the level of total savings, we can construct the following simple model of economic growth:

Saving $(\mathrm{S})$ is some proportion, s, of national income $(\mathrm{Y})$ such that we have the simple equation

$S=s Y$

Net investment $(I)$ is defined as the change in the capital stock, $K$, and can be represented by $\Delta K$ such that $I=\Delta K$

But because the total capital stock, $K$, bearsa direct relationship to total national income or output, $Y$, as expressed by the capital-output ratio, $k$, it follows that

$K / Y=k O R \Delta K / \Delta Y O R \mathrm{~K} / \Delta \mathrm{Y}$

Or, finally,

$\Delta K=\Delta k \Delta Y$

Finally, because net national savings, $S$, must equal net investment, $I$, we can write this equality as $S=I$

But from Equation 1 we know that $S=\Delta s Y$ and from Equations 2 and 3 we know that

$I=\Delta K=k \Delta Y$

It therefore follows that we can write the "identity" of saving equaling investment shown by Equation 2.4 as $S=s Y=k \Delta Y=\Delta K=I$

Or simply as $s Y=k \Delta Y$

Dividing both sides of Equation 7 first by $Y$ and then by $k$, we obtain the following expression:

$$
\frac{\Delta Y}{Y}=\frac{s}{k}
$$

Note that the left-hand side of Equation $8, \Delta Y / Y$, represents the rate of change or rate of growth of GNP (i.e., it is the percentage change in GNP). Equation 8, which is a simplified version of the famous equation in the Harrod-Domar theory of economic growth,2 states simply that the rate of growth of GNP $(\Delta Y / Y)$ is determined jointly by the national savings ratio, $s$, and the national capital-output ratio, $k$.More specifically, it says that in the absence of government, the growth rate of national income will be directly or positively related to the savings ratio (i.e., the more an economy is able to save - and invest - out of a given GNP, the greater the growth of that GNP will be) and inversely or negatively related to the economy's capital-output ratio (i.e., the higher $k$ is, the lower the 
rate of GNP growth will be). The economic logic of Equation 8 is very simple. In order to grow, economies must save and invest a certain proportion of their GNP. The more they can save and invest, the faster they can grow. But the actual rate at which they can grow for any level of saving and investment - how much additional output can be had from an additional unit of investment — can be measured by the inverse of the capital output ratio, $k$, because this inverse, $1 / k$, is simply the output-capital or output investment ratio. It follows that multiplying the rate of new investment, $s=I / Y$, by its productivity, $1 / k$, will give the rate by which national income or GNP will increase.

\section{The Solow Growth Model}

The Solow-Swan model is an economic model of long-run economic growth set within the framework of neoclassical economics. It attempts to explain long-run economic growth by looking at capital accumulation, labor or population growth, and increases in productivity, commonly referred to as technological progress. At its core is a neoclassical (aggregate) production function, often specified to be of Cobb-Douglas type, which enables the model "to make contact with microeconomics. The model was developed independently by Robert Solow and Trevor Swan in 1956, and superseded the Keynesian Harrod-Domar model.

Mathematically, the Solow-Swan model is a nonlinear system consisting of a single ordinary differential equation that models the evolution of the per capita stock of capital.

The Solow growth model is built on a closed economy which makes use of labour and capital as its means of production. Under this scenario the implication of capital stocks on growth can be seen through its effect on the domestic saving which in turn used as investment in a closed model. Those countries which transfer revenue from export earnings which can be used in investment in the economy to avoid huge growth and will discourage public investment. This in turn will decrease economic growth and will shift both the investment and production function curves in Solow growth model downward (Adedoyi, Babalola, Otekunri, \& Adeoti, 2016).

Consequently, in Solow's model, other things being equal, saving/investment and population growth rates are important determinants of economic growth. Higher saving/investment rates lead to accumulation of more capital per worker. In the absence of technological change and innovation, an increase in capital per worker would not be matched by a proportional increase in output per worker because of diminishing returns. Hence capital deepening would lower the rate of return on capital.

\section{Review of the empirical literature}

Aremu, Suberu, \& Ladipo, (2011) argue across four different measures that were combined into a single index of capital market development through component analysis, while market financial depth is being as control. The study reveal that capital market development has inverse relationship with economic growth and significant long run impact on growth process in Nigeria. While, Donwa \& Odia, (2010) examines the empirical impact of Nigerian stock market on economic between 1981 and 2008. The study employed ordinary least square (OLS) and it was reveal that Nigeria's capital market does not have significant impact on the economic growth. In view of this, the scholars recommended that investors' confidence should be stemmed along with activities 
at the stock market in order to make security market contribute significantly to economic growth in future. Meanwhile, Babalola \& Adegbite (2001) in their study of the performance of the Nigerian capital market since deregulation in 1986, submits that the Nigerian capital market is shallow and it is without expected variety, through rigorous discussion on financial delivery, financial service that centered on evolution, performance and prospects. Although, it was argued that market prospects are bright based on the recent efforts of government towards commercialization and privatization drive of enterprises but the authors recommended that government need to appropriate regulatory framework inform of investors guide so as to attain growth objectives through continuous provision of long term funds for productive services.

Bekaert \& Harvey, (1997) study the link between financial market and economic growth with much emphasis on capital market and stock market integration through ranked order correlation and it discovered that projects in capital market have higher discount ratio since required rate of return is linked to local market volatility. Therefore, the study suggests that openness of the small open economy is positively correlated to economic growth. Whereas, Godfrey \& Mutuku (2013) investigated the nexus between national output and internal borrowing in Kenya, through sophisticated statistical approach between from 2000 to 2010. The unit root test of Augmented Dickey, cointegration and ARDL bound testing techniques. The results indicate that increase in internal borrowing via capital market improves economic growth. As a result, the findings suggest an increase in borrowing through capital market, in as much as it is channeled towards productive investment.

While, Osuala, Okereke, \& Nwansi (2013) work from different economy with different perspectives. In their study, which was based on stock market performance and economic growth in Nigeria. The findings reveal that stock market really enhance economic, using the general-to-specific Autoregressive Distributed Lag (ARDL) /bound testing approach. The study hence suggests that regulatory authorities should reactivate the interest of both local and foreign investors in order to sustain growth. In the same vein, Nurudeen (2009) posits that stock market development guarantee economic growth in Nigeria. The study employs error correction approach, which reveal that market capitalization-GDP ratio influences economic growth. And the author therefore suggests that removal of impediments such as tax, legal requirements from the stock market is necessary and the nation's infrastructure should be improved in order to create an enabling environment for the market to operate smoothly.

In so far, most of the previous works were not specifically designed to examine the impact of capital market on the Nigeria economic growth in both narrow and broader terms concurrently, rather they either addressed the phenomenon in narrow term or broader term, the few ones that attempted to address it instantaneously were not based on the Nigeria economy e.g. Godfrey \& Mutuku (2013). Hence, it is pertinent to proceed on this study at this critical period.

\section{METHODS}

Over the years, different methodological approaches have been explored by previous authors. Hence, this study intends to investigate the nexus between capital 
market and economic growth in Nigeria between 1980 and 2017 through descriptive statistical analysis, auto-regressive distribution lag model and Bound Cointegration Testing (Nurudeen, 2009; Osuala, Okereke, \& Nwansi, 2013). Also, post estimation tests were conducted to know whether econometric estimation of the parameters has theoretical backing and statistically significant. Going forward, the study attempts to explain long-run economic growth through the Solow growth model is an economic model via capital accumulation, labor or population growth, and increases in productivity, which is commonly referred to as technological progress (Solow, 1956).

Where, $\quad Y=F(K, L, T)$

$\mathrm{Y}=$ output, $\mathrm{K}=$ Capital input, $\mathrm{L}=$ Labor input, $\mathrm{T}=$ Technical Progress.

The model in equation (9) is therefore specified

$Y=f(K, L, T)$

Introducing the explanatory variable of capital market, the model in equation (10) above is hereby specified as

$$
Y=f(M C P, G C F)
$$

Where MCP denotes market capitalization, GCF explains the gross capital formation and other regreesors to be included in the model are exchange rate (EXR), interest rate (INT), all shares index (ASI), and number of deals (NDL).

$\mathrm{RGDP}=f(M C P, G C F, E X R, I N T, A S I, N D L, V A T)$

So that we have the model in its transformed state as:

$Y=\beta_{0}+\beta_{1} M C P+\beta_{2} G C F+\beta_{3} E X R+\beta_{4} I N T+\beta_{5} A S I+\beta_{6} N D L+\beta_{7} V A T+\mu \ldots$

Where:

$\mathrm{Y}=$ Real Gross Domestic Product, MCP=Market Capitalization, GCF=Gross Capital Formation, EXT=Exchange Rate, INT=Interest Rate, ASI $=$ All Share, NDL=Number Deals, VAT $=$ Value of All Transaction, $\mu=$ Stochastic error term, $\beta_{1}, \beta_{2}, \beta_{3}, \beta_{4}, \beta_{5}, \beta_{6}$, which implies the slope of the regression equation.

The model is specified of its log-linear form:

$\log \mathrm{RGDP}=\beta_{0}+\beta_{1} \log M C P+\beta_{2} \log G C F+\beta_{3} E X R+\beta_{4} I N T+\beta_{5} \log A S I+$

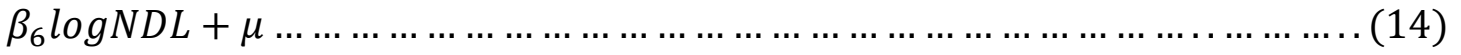

Notably, series were logged due to large nature of some numbers especially Real Gross Domestic Product (RGDP) and Gross Capital Formation (GCF).

\section{RESULT AND DISCUSSION}

In this section, the study presents data analysis and the results. It begins with descriptive statistics followed by the trend analysis of capital market indicator(s) on real gross domestic product.

\section{Descriptive statistics}

Descriptive statistics shows the qualities of the data that are been used for estimation, the knowledge of which allow us to define the appropriate methodology for estimation. The Table 1 summarize the descriptive statistics. 
Table 1. Summary of the variables

\begin{tabular}{lrrrrrrrr}
\hline & GDP & \multicolumn{1}{l}{ ASI } & \multicolumn{1}{l}{ EXC } & \multicolumn{1}{l}{ INT } & NDL & VAT & MCP & GCF \\
\hline Mean & 3.208542 & 17684.47 & 82.66459 & 0.038366 & 985343.9 & 360053.1 & 2781.623 & 38.20338 \\
Median & 4.230061 & 6992.1 & 92.3381 & 3.023542 & 123509 & 14072 & 302.5825 & 37.23967 \\
Maximum & 15.32916 & 173285.8 & 305.7901 & 18.18 & 12112690 & 2350876 & 13226 & 89.38105 \\
Minimum & -13.12788 & 10.4000 & 0.617708 & -65.85715 & 10014 & 215 & 1.2 & 14.90391 \\
Std. Dev. & 5.610974 & 30119.77 & 80.3356 & 14.95721 & 2095995 & 570043.4 & 3998.123 & 19.1784 \\
Skewness & -15.32916 & 3.89932 & 0.717369 & -2.538242 & 4.26444 & 1.781894 & 1.3071 & 0.894633 \\
Kurtosis & 4.453574 & 20.49326 & 2.879241 & 11.58989 & 22.81296 & 5.748037 & 3.364433 & 3.513784 \\
Jarque-Bera & 8.012825 & 565.5341 & 3.195963 & 153.4834 & 717.3302 & 31.22229 & 10.74057 & 5.342565 \\
Probability & 0.018199 & 0.0000 & 0.202304 & 0.0000 & 0.0000 & 0.0000 & 0.004653 & 0.069163 \\
Sum & 118.7161 & 654325.4 & 3058.59 & 1.419531 & 36457725 & 13321963 & 102920.1 & 1413.525 \\
Sum Sq. Dev. & 1133.389 & $3.27 \mathrm{E}+10$ & 232337.1 & 8053.857 & $1.58 \mathrm{E}+14$ & $1.17 \mathrm{E}+13$ & $5.75 \mathrm{E}+08$ & 13241.19 \\
Observations & 37 & 37 & 37 & 37 & 37 & 37 & 37 & 37 \\
\hline
\end{tabular}

From the Table 1, GDP represents Gross Domestic Product, ASI represents all share index, EXC denotes exchange rate, INT denotes interest rate, and NDL means number of deals, VAT symbolizes value added tax, MCP explains market capitalization and GCF implies gross capital formation. The estimated mean value is been used to examine the pattern of distribution and the figures values for GDP ASI EXC INT NDL VAT MCP and GCF are 4.230061, 6992.1, 92.3381, 3.023542, 123509, 14072, 302.5825 and 37.23967 separately. The results also reveals that the standard deviation showed that ASI NDL, VAT and MCP 30119.77 2095995, 570043.4 and 3998.123 demonstrates high variability, while GDP, EXC, INT and GCF show low variability.

In conclusion, all the variables under this study are widely dispersed around their means indicating that they are grossly affected by their extreme value. ASI EXC NDL VAT MCP and GCF has positive skewness while GDP and INT are negatively skewed. Kurtosis is either flat or peak of the normal curve. It measures of the "tailedness" of the probability distribution of a real-valued random variable. It is normal distribution and mesokurtic if kurtosis equal 3, platykurtic if kurtosis less than 3 and leptokurtic if kurtosis greater than 3. In the study, all series were leptokurtic in their distribution except EXC that is platykurtic. Jarque-Bera is used to test whether the estimates are normally distributed or not. It is observed that $5 \%$ level of insignificant indicates that the residuals are normally distributed.

It can be observed from the harmonized curve that over the years, number of dealings in capital market and all share index rise sporadically on gross domestic products compared to other series like exchange rate, gross capital formation, market capitalization and volume of trade that disclose smooth and steady movement on gross domestics products. 


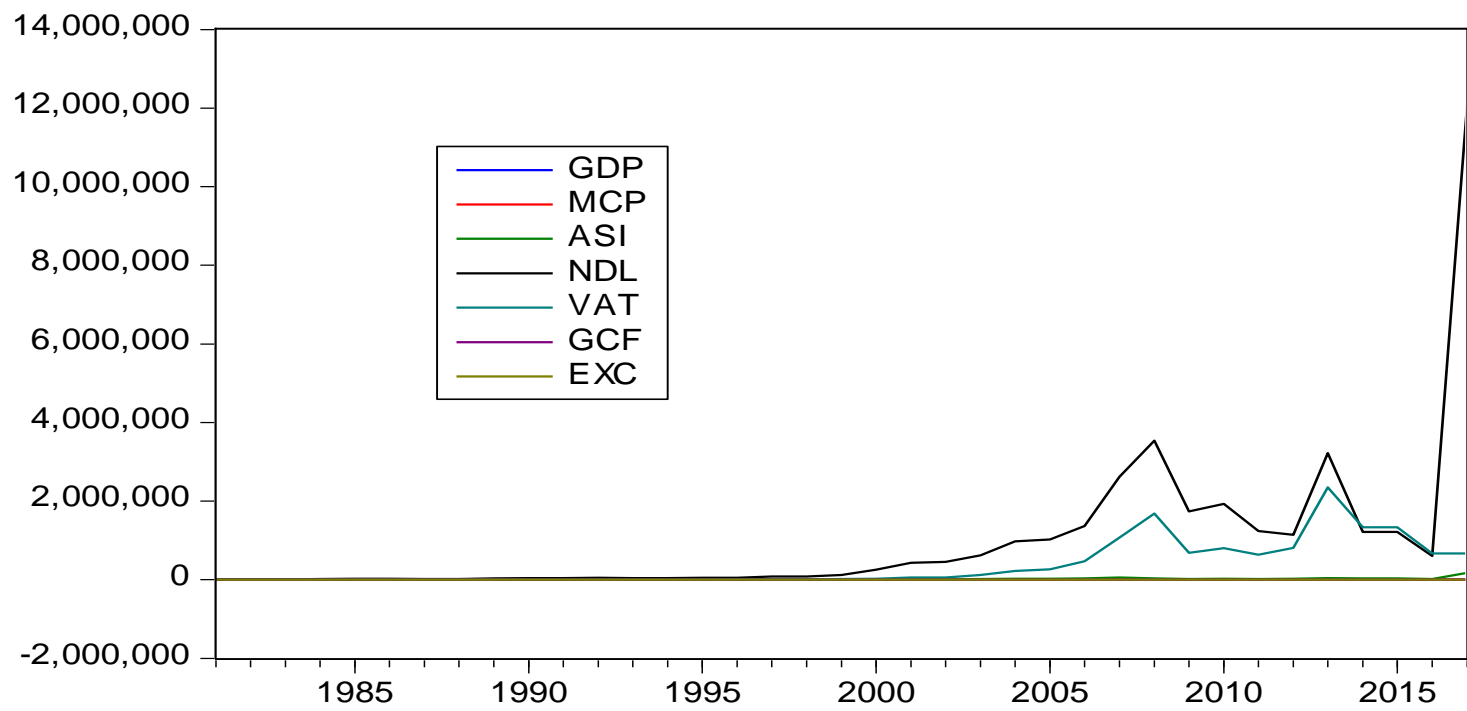

Figure 1. The trend analysis (harmonized curve)

The categorical curves explain the individual specifics of the series employed in the study. The GDP curve shows moderate movement over time, while series like MCP, ASI, NDL, and EXC disclose slow start but later rise spontaneously over the years. Meanwhile, GCF rise initially but later drastically drop later on.

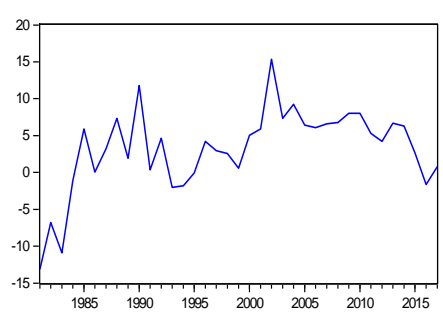

NDL

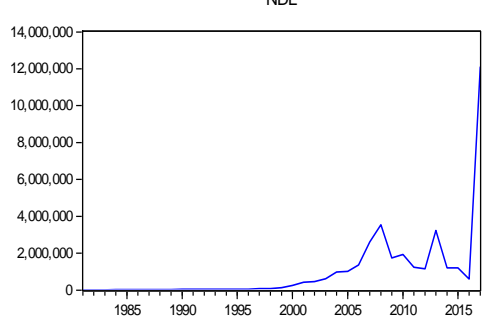

EXC

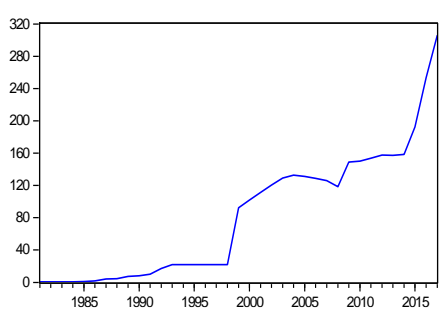

Figure 2. Categorical curve
MCP

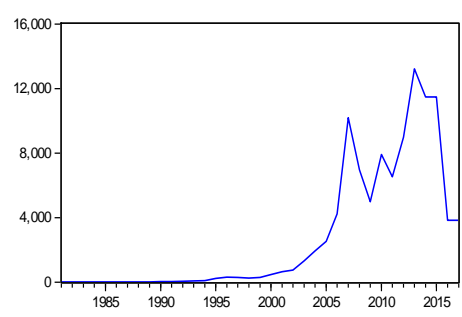

VAT

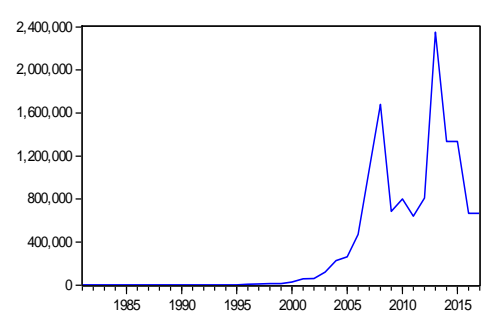

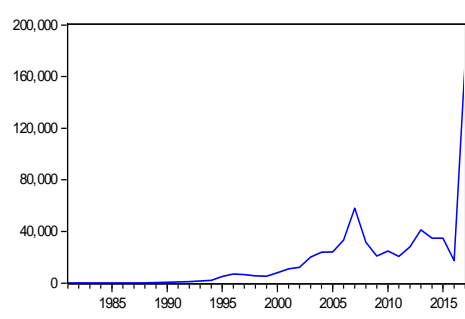

GCF

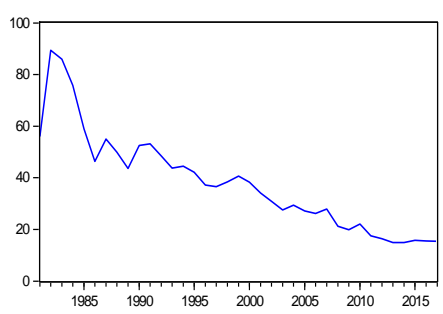

From Table 2. unit root and statistical attributes of all the series were tested. It shows the estimates of level and first difference of the variables in the model. The null hypothesis states that there is a unit root in each of the series that is each variable is non stationary. 
Table 2. Unit root test

\begin{tabular}{ccc}
\hline Unit root test & ADF T-Statistics & Order of integration \\
\hline GDP & -4.045483 & $\mathrm{I}(0)$ \\
ASI & -4.278503 & $\mathrm{I}(1)$ \\
EXC & -3.297372 & $\mathrm{I}(1)$ \\
INT & -7.068039 & $\mathrm{I}(0)$ \\
NDL & -4.058280 & $\mathrm{I}(1)$ \\
VAT & -7.620459 & $\mathrm{I}(1)$ \\
MCP & -6.204511 & $\mathrm{I}(1)$ \\
GCF & -5.530699 & $\mathrm{I}(1)$ \\
\hline
\end{tabular}

Intuitively, the null hypothesis cannot be rejected if the ADF statistic is greater than critical value at various significance levels. Augmented Dickey Fuller reveals that GDP and INT are integrated at level I (0), while series of ASI, EXC, NDL, VAT, MCP, and GCF. This kind of conflict between the outcomes of the two tests is common in practice (Rahman, 2012). Based on the mixed ADF test results, the condition for Auto-Regressive Distributed Lag (ARDL) and Bound cointegration testing are met.

\section{ARDL analysis}

This subsection presents the result obtained from estimating the ARDL unrestricted error correction (short run or dynamic) model and the ARDL short run (static) model in equation. Following this result, this study examines and estimates both short-run dynamics and the long-run relationships between gross domestic products, all share index, interest rate, and number of deals, market capitalization, exchange rate and gross capital formation.

Table 3. ARDL coefficient

\begin{tabular}{lrrrr}
\hline Variables & \multicolumn{1}{c}{ Coefficient } & \multicolumn{1}{c}{ Std. Error } & \multicolumn{1}{c}{ t-Statistic } & Prob. \\
\hline D(LOG ASI) & $1.75 \mathrm{E}-05$ & $4.21 \mathrm{E}-05$ & 0.415287 & 0.6813 \\
ASI(-1) & $-0.000177^{*}$ & 0.000127 & -1.388744 & 0.0767 \\
EXC(-1) & -0.039751 & 0.041162 & -0.965725 & 0.3431 \\
INT(-1) & $0.026805^{* *}$ & 0.061335 & 0.437028 & 0.0294 \\
LOGNDL(-1) & $4.501125^{*}$ & 2.39939 & 1.875946 & 0.0719 \\
LOGVAT(-1) & 0.040172 & 1.334997 & 0.030092 & 0.9762 \\
LOGMCP(-1) & -0.564331 & 1.121217 & -0.50332 & 0.6190 \\
LOGGCF(-1) & 1.224539 & 4.651449 & 0.26326 & 0.7944 \\
LOGGDP(-1) & $-0.813671^{* * *}$ & 0.2129 & -3.821852 & 0.0007 \\
C & $-47.45991^{*}$ & 27.4222 & -1.730711 & 0.0954 \\
\hline
\end{tabular}

Figures in parenthesis indicates (*) (**) (***) for 1\%, 5\% and $10 \%$ level of significance respectively.

\section{Bound test}

It is used to test the presence of long-run equilibrium between the series. Based on the mixed outcome, it is pertinent to investigate long-run presences in the model. Thus, given the unit root test result above, the most appropriate co-integration test is the Pesaran Bounds test since the test allows combination of fractionally integrated variables i.e. combines variables of different orders of integration. The Bounds Cointegration test result is provided thus: 
Table 4. ARDL bounds test

\begin{tabular}{lll}
\hline Test Statistic & Value & $\mathrm{k}$ \\
\hline F-statistic & 4.635011 & 5 \\
\hline Critical Value Bounds & & \\
\hline Significance & $\mathrm{I}(0)$ Bound & $\mathrm{I}(1)$ Bound \\
\hline $10 \%$ & 2.03 & 3.13 \\
$5 \%$ & 2.32 & 3.50 \\
$2.50 \%$ & 2.60 & 3.84 \\
$1 \%$ & 2.96 & 4.26 \\
\hline
\end{tabular}

Source: Author's calculation.

Bounds test, the result above shows that the assumption of null hypothesis of no long-run relationship can be rejected, as the F-statistics estimates fall out the upper bound across the various level of significance. The F-statistic for the model is greater than $1 \%$, $5 \%$ of both I (0) and I (1) bounds of 2.96 and 3.50 respectively. Thus, this confirms the existence of long-run relationship between real gross domestic products, all share index, interest rate, and number of deals, market capitalization, exchange rate and gross capital formation.

\section{Long-run ARDL and Error Correction Model analysis}

It is confirmed from the result that there is a positive relationship with interest rate past number of deals and previous year gross domestic products significant at $1 \%, 5 \%$ and $10 \%$ respectively. The co integration equation is:

$$
\begin{aligned}
& \text { Cointeq }=\text { LOGGDP }-(-0.0003 * \text { ASI }-0.0458 * E X C+0.0989 * I N T+6.5135 \\
& \\
& \quad * \text { LOGNDL }-1.2503 * \text { LOGVAT }-0.6097 * \text { LOGMCP }-5.1950 * \text { LOGGCF } \\
&-34.1743)
\end{aligned}
$$

When co integration exists, the Engle-Granger Theorem establishes the encompassing power of the error correction mechanism over other forms of dynamic specifications. The next section reports the results of the Error Correction Mechanism.

Table 5. ARDL ECM

\begin{tabular}{lrrrr}
\hline Variables & Coefficient & \multicolumn{1}{c}{ Std. Error } & \multicolumn{1}{c}{ t-Statistic } & \multicolumn{1}{l}{ Prob. } \\
\hline D(ASI) & $-0.000107 * *$ & 0.000049 & -2.188634 & 0.0378 \\
D(EXC) & $-0.04478^{*}$ & 0.025623 & -1.747659 & 0.0923 \\
D(INT) & 0.096609 & 0.076105 & 1.269412 & 0.2155 \\
D(LOGNDL) & $6.36512^{* * *}$ & 2.034601 & 3.128437 & 0.0043 \\
D(LOGVAT) & -1.221797 & 1.18076 & -1.034755 & 0.3103 \\
D(LOGMCP) & -0.595856 & 1.235426 & -0.482308 & 0.6336 \\
D(LOGGCF) & $-5.07664^{* * *}$ & 4.80264 & -1.057052 & $0.0032 * * *$ \\
CointEq(-1)* & $-0.97722^{* * *}$ & 0.181198 & -5.393114 & $0.0000^{* * *}$ \\
\hline R-squared & 0.782838 & Mean dependent var & 3.662332 \\
Adjusted R-squared & 0.762638 & S.D. dependent var & 4.954355 \\
S.E. of regression & 3.701278 & Akaike info criterion & 5.685366 \\
Sum squared resid & 356.1858 & Schwarz criterion & 6.125233 \\
Log likelihood & -92.33659 & Hannan-Quinn criter. & 5.838891 \\
Durbin-Watson stat & 2.271296 & & & \\
\hline
\end{tabular}

Figures in parenthesis indicates (*) (**) (***) for $1 \%, 5 \%$ and $10 \%$ level of significance respectively. 
Table 6. Diagnostic test result

\begin{tabular}{ll}
\hline Test & F-Stat (Prob) \\
\hline Jarque-Bera test & $3.477247(0.175762)$ \\
Breusch-Godfrey test & $0.515344(0.8500)$ \\
\hline
\end{tabular}

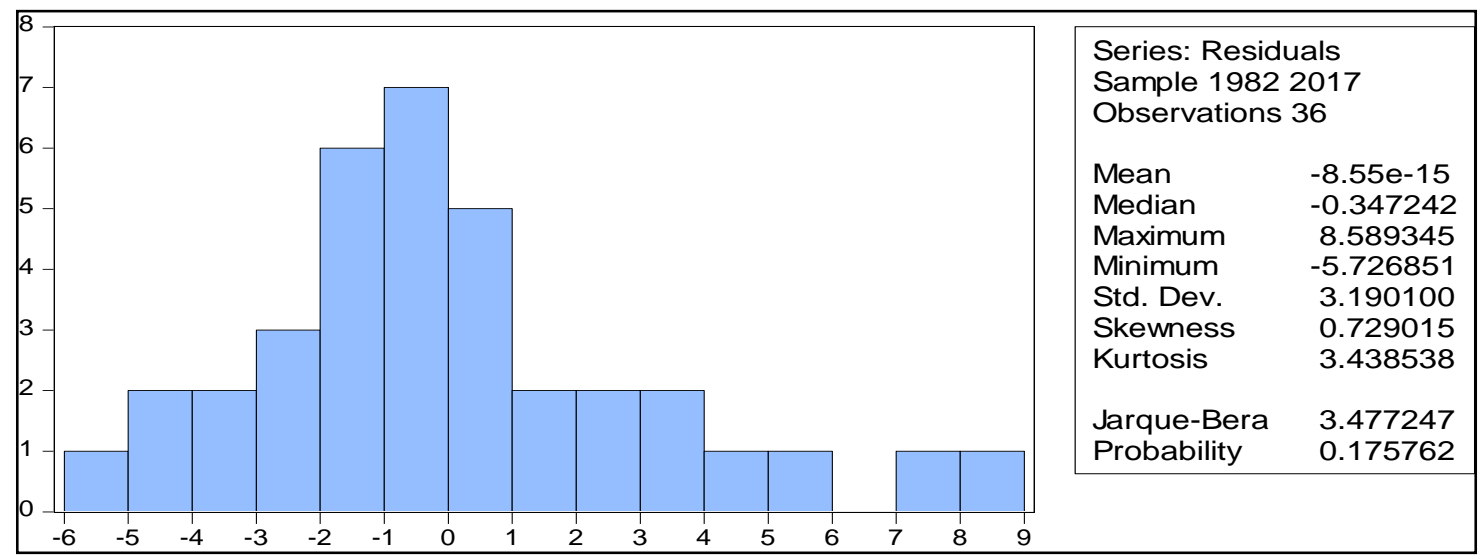

Figure 3. Normality curve

\section{Discussion}

From Table 3, it can be observed that previous year of ASI, INT, NDL and GDP are statistically significant. Meaning that previous years activities of the variables predicts present year's effects on economic growth in Nigeria. It is worthy to note that the series in the model have short run significant impact on the Nigeria's economic, that capital market indicators have significant effect on the economic growth of Nigeria. However, series like current All share index, previous value of share traded, previous and previous gross capital formation are all positive to current gross domestic products, except for exchange rate and market capitalization which are negative and not statistically significant. Meanwhile, Donwa \& Odia, (2010) examines the empirical impact of Nigerian stock market on economic between 1981 and 2008. The study employed ordinary least square (OLS) and it was reveal that Nigeria's capital market does not have significant impact on the economic growth.

Interestingly, the Bound test estimates established the presence of long run relationship between the series in the model. The higher F-statistics which is greater than both lower and upper bound critical value disclose that long run analysis is pertinent in this study. The results from long run form model further reveal that capital market has long run significant impact on economic growth in Nigeria.

The cointegration test for the long run relationship reveals that capital market has significant impact on the Nigeria's economic growth through all share index, exchange rate, number of deals, and gross capital formation. Furthermore, the series disclose different level of significance ranges from $1 \%$ to $10 \%$. For example, 1 percent rise in all share index brings about 0.01 percent fall in economic growth, while 1 unit rise in number of dealings at the capital market brings about 636.5 units rise in economic growth. A unit rise in gross capital formation brings about 507.6 units fall in economic growth verse 
versa.

Notably, the error correction mechanism results disclose that there is link between the short run and long run effects of capital market on economic growth in Nigeria. This portrays the speed at which level of disequilibrium recon verge from the short run disruption to long run at the rate of $97.7 \%$. This rate indicates how quick the model readjusted over time and at a very high speed. The R-square explains the level of determination in the model, that is, it is used to measure the level at which independent variables explain the dependent variable over the period under discussion. R-square simply refers to as co-efficient of determination reveals that 78 percent of the gross domestic is explained by the regressors which means that our model is good and fit for the analysis. The Durbin-Watson statistic shows that there is not auto-correlation in the model adopted at 2 .

After estimating the short and long-run analysis, it is required to verify whether our results are valid and in line with the OLS technique assumptions, that is, how efficiency and consistency are the results estimated so far within the model. From Table 6, JarqueBeta test suggest that the residuals for both models are normally distributed since the probability value is greater than 5\% significant level. Hence, the hypothesis of normal distribution for residuals cannot be rejected. The Breusch-Godfrey Serial Correlation (LM) test re-affirms that the hypothesis of no autocorrelation cannot be rejected since the probability value is greater than $5 \%$ critical value. The normality test reveals that the series are normally distributed.

\section{CONCLUSION AND RECOMMENDATION Conclusion}

In so far, the study explored nexus between capital market and economic growth in Nigeria, from 1980 to 2017 through annual time series data. This study addresses different questions being raised in the cause of the research. It is interesting to note that the study made use of ARDL and Bound Cointegration techniques to explain the long-run and short-run relationship between capital market and economic growth in Nigeria. Remarkably, the Bound test was used to investigate whether there is long-run cointegration and it revealed that the variables co-integrated in the long run.

Having empirically sought for the link between capital market and the Nigerian economic growth between 1980 and 2017, it is predominantly concluded that long-run and short-run relationship between capital market and economic growth in Nigeria subsist. Meaning that that capital market has significant effects on the Nigerian economic growth during the years under review, which corroborate the views of Osuala, Okereke, and Nwansi (2013), Afees, and Kazeem, (2010).

\section{Recommendation}

Drawing from the current revelations, this study henceforward, recommends that government should expand the technological based of the Nigerian capital market in order to further improve transactions and dealings, which could enhance internationalization and competitiveness of the market. Also, regulatory body like security and exchange commission (SEC) should improve its supervisory roles towards reducing shoddy and unethical dealings in the Nigerian capital market. 


\section{REFERENCES}

Adam, J. A., \& Sanni, I. (2005). Stock Market Development and Nigeria's Economic Growth. Journal of Economics and Allied Fields, 2(2), 116-132.

Adedoyi, L.I, Babalola, M.B, Otekunri, A.O, \& Adeoti, J.O. (2016) External Debt and Economic Growth: Evidence from Nigeria. Acta Universitatis Danubius, 12 (6), 179-194.

Afees, A.S \& Kazeem, B.A (2010). The Stock Market and Economic Growth in Nigeria: An Empirical Investigation, Journal of Economic Theory, 4, 65 - 70.

Aremu, O. S. Suberu, O. J. Ladipo, \& O.O. (2011) Impact of the Nigerian capital market operations on the local investments in Nigeria. Journal of Research in International Business Management, 1(8), 258-261.

Alile, H.1 (1984). The Nigerian Stock Exchange: Historical Perspectives, operations and Contributions to Economic Development, Central Bank of Nigerian Bullions 2: 6S$6 \mathrm{Q}$.

Anyanwu, J.C (1993). Monetary Economics Theory, Policy and Institutions. Onitsha: Hybrid Publishers Ltd., pp. 247 - 27.

Banerjee, V.A (2001) Contracting Constraints, Credit Markets and Economic Development. Department of Economics MIT, 1-55.

Babalola, J. A. \& Adegbite, M. A. (2001). The performance of the Nigerian capital market since deregulation in 1986. Economic and Financial Review, 39(1), 1-19.

Bekaert, G., \& Harvey, C.R. (1997): Emerging equity market volatility. Journal of Financial Economics 43, 29-78.

Capital Market Authority (2008). To regulate and promote a robust, transparent, fair and efficient capital market in Uganda. Annual report: 30 June 2008.

Donwa J.P. \& Odia J. Odia (2010) An Empirical Analysis of the Impact of the Nigerian Capital Market on Her Socio-economic Development. Journal of Social Sciences, 24(2):135-142.

Ekundayo, K. (2002). The Nigeria capital market report on operational activities. CBN Annual Report account Central Bank of Nigeria Publication the capital market and its impact on the growth of the Nigerian economy. 25(1), 11

Engle, R.F. \& Granger, C.W.J. (1987) Cointegration and Error Correction Representation, Estimation and Testing. Econometrica, 55(2), 252-276.

Ewah, S.O.E, Esang, A.E. \& Bassey J.U. (2009). Appraisal of Capital Market Efficiency on Economic Growth in Nigeria. International Journal of Business and Management, 4 (12), 219 - 225.

Ewan D (2009). Stock prices and exchange rate interactions in Nigeria. IUP J. Fin. Econ. $2,40-43$

Godfrey, K.P. \& Cyrus, M.M. (2013) Domestic Debt and Economic Growth Nexus in Kenya, Current Research Journal of Economic Theory, 5(1), 1-10

Granger, C. W.J. \& P. Newbold. (1977). Forecasting Econometric Time Series. New York: Academic Press.

Hamid, M. \& Sumit, A. (2007). Stock Market Development and Economic Growth: Evidence from Developing Countries. University of Wisconsin- Milwaukee, WI 53201. 
Levine, R. (1991). Stock Markets, Growth, and Tax Policy. Journal of Finance, XLVI, $1445-1465$.

Levine, R. (1997). Financial Development and Economic Growth: Views and Agenda. Journal of Economic Literature, XXXV, 688-726.

Levine R, \& Zervos, S. (1998). Stock Market Development and Long-run Growth. American Economic Review, 88(3), 537- 558.

Muhammed, S., Nadeem, A., \& Liaquat, A. (2008). Stock Market Development and Economic Growth: ARDL Causality in Pakistan. International Research Journal of Finance and Economics, 14,.183- 195.

Nurudeen, A. (2009). Does stock market development raise economic growth? Evidence from Nigeria. The Review of Finance and Banking, 1(1), 015-026.

Nyong, M.O. (1997). Capital Market Development and Long-run Economic Growth: Theory, Evidence and Analysis. First Bank Review, 13-38.

Oke M.O. \& Azeez B.A. (2012) A Test of Strong-Form Efficiency of the Nigerian Capital Market. Business Systems review, 1(1), 10-26.

Okereke, O. (2000). A critical study of the difference between capital market development and economic growth in Nigeria. SEC publication 1997, 2-4.

Omole, D.O. (1997). Efficient market hypothesis and the Nigerian capital market under financial liberalization: An empirical analysis. (Unpublished $\mathrm{PhD}$ Thesis), University of Ibadan, Nigeria.

Osaze B.E. (2000). The Nigerian Capital Market in the African and Global Financial System. Benin City: Bofic Consults Group Limited.

Osinubi, T. S., \& Amaghionyeodiwe, L.A. (2003). Stock Market Development and Long-run Growth in Nigeria. Journal of African Business, 4 (3), 103-129.

Osuala, A. E, Okereke, J.E \& Nwansi, G.U. (2013) Does stock market development promote economic growth in emerging markets? A causality evidence from Nigeria. World Review of Business Research, 3(4), 1-13.

Odetayo T.A \& Sajuyigbe A.S. (2012) Impact of Nigerian capital market on economic growth and development. International Journal of Arts and Commerce, 1(5), $1-8$.

Solow, R. M. (1956). A contribution to the theory of Economic Growth. Quarterly Journal of Economics, LXX(70), 65-99.

Soyode A (1990) The role of capital market in economic development. Security Market Journal, 6(2).

Osinubi, T.S. (2002) Does Stock Market Promote Economic Growth in Nigeria? Available at: https://www.semanticscholar.org/paper/Does-Stock-Market-PromoteEconomic-Growth-In-Osinubi/08ca7e476f50076c284920d2e4c32bb821d12bf2

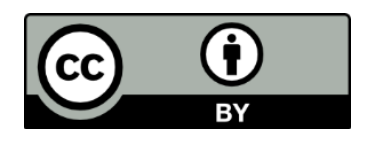

(C) 2020 by the authors. Licensee JPPD, Indonesia. This article is an open access article distributed under the terms and conditions of the Creative Commons Attribution (CC BY) license (http://creativecommons.org/licenses/by/4.0/). 